\title{
APPLICATION OF PEDICLE FLAPS FOR WOUND COVERAGE OF LOWER LEG
}

\author{
Yolanda K. Zayakova \\ Department of Burns, Plastic and Aesthetic Surgery, Multi-profile Hospital for \\ Active Treatment - Varna, Military Medical Academy - Sofia
}

\begin{abstract}
SUMMARY
This paper presents 11 clinical cases with soft tissue defect of lower leg and foot. The reconstructive surgery of the wounds involves 14 pedicle flaps: five of which are gastrocnemius; nine are sural flaps. The etiology of the defects is various: 6 of the patients are with deep burns of the lower limbs; 3 with deep frostbite; 2 with different trauma. The patients are aged between 27 and 79. The obtained results and the applied reconstructive methods in the treatment of soft tissue defects of the lower extremities are discussed.
\end{abstract}

Keywords: flap, burns, foot, lower leg

\section{INTRODUCTION}

The reconstructive treatment of deep soft tissue defects of the lower limbs presents quite a challenge to the surgeon because of the anatomy and functional characteristics of the body area involved. Particular attention is required when treating traumatized knee, ankle joints and foot. Split-skin or full-thickness graft is generally applied in deep trauma involving only the skin, while cases with exposed tendons, bones and ligaments require a different surgical approach and more stable soft-tissue coverage (1). The excision of non-vital tissue may lead to opening of the joint, therefore it is vital that the surgery should both stabilize the joint and restore its full mobility. In such cases the method of choice is a flap which may be pedicle or free (2).

\section{MATERIALS AND METHODS}

During the period 2001-2010 fourteen pedicle flaps were applied in 11 patients. The age of the patiens was between 27 and 79. The cases are: five with deep knee burn; one with burn in both feet, three with frostbite; two with different trauma. The Application of the flap is determined by the size, location and the depth of the defect, regardless of the etiology of the wound. The accompanying diseases are not considered contraindications for treatment with flaps. Five reconstructions were performed with gastrocnemius flap, nine with sural flap. The medial head of gastrocnemius was used in four patients and the lateral head in one. A subcutaneous tunnel at the level above the proximal part of the tibia is formed medially or laterally depending on which muscle head is going to be used. The flap is passed through the subcutaneous tunnel and is spread over the anterior surface of the knee joint. It is fixed to the wound edges by single stitches. The muscle is covered with a split skin graft meshed at a 2:1 ratio. S u r a 1 flaps were elevated as a fasciocutaneus flaps, including the neurovessel bundle and strip of deep fascia $2,5 \mathrm{~cm}$ wide. The dimensions of the smallest sural flap were $6.5 \times 7 \mathrm{~cm}$ and the measurements of the biggest one were $8 \times 10 \mathrm{~cm}$. The donor site was covered with free skin graft. Two cases with frostbite required simultaneous application of two sural flaps to both feet.

\section{RESULTS}

Successful results were observed in $10(83,33 \%)$ cases. Complete tissue coverage and good function of the injured joints and feet were achieved. Partial lesion of the free skin graft was observed in two patients $(16,67 \%)$ with $\mathrm{m}$. gastrocnemius flap which did not require additional surgery. One $(11,11 \%)$ complete flap loss of sural flap was observed. After wound granulation, full thickness skin graft was applied and the result was satisfactory. Distal edge necrosis appeared in $4(44,44 \%)$ cases. Two of them were caused by compression of the flap because the patients failed to observe the postop rules. The skin island was lost in two patients who suffered from diabetes. In the last two cases the defects were covered with full skin graft.

\section{CLINICAL CASES}

Patient No. 1 Male aged 44 with deep frostbite. After demarcation of the necrotic tissue, the patient underwent a transmetatarsal amputation. Two sural flaps were applied with skin island size $7,5 / 9 \mathrm{~cm}$. and $7 / 8 \mathrm{~cm}$. Total loss of the flaps on the left calcaneus was observed. The defect was skin grafted. 

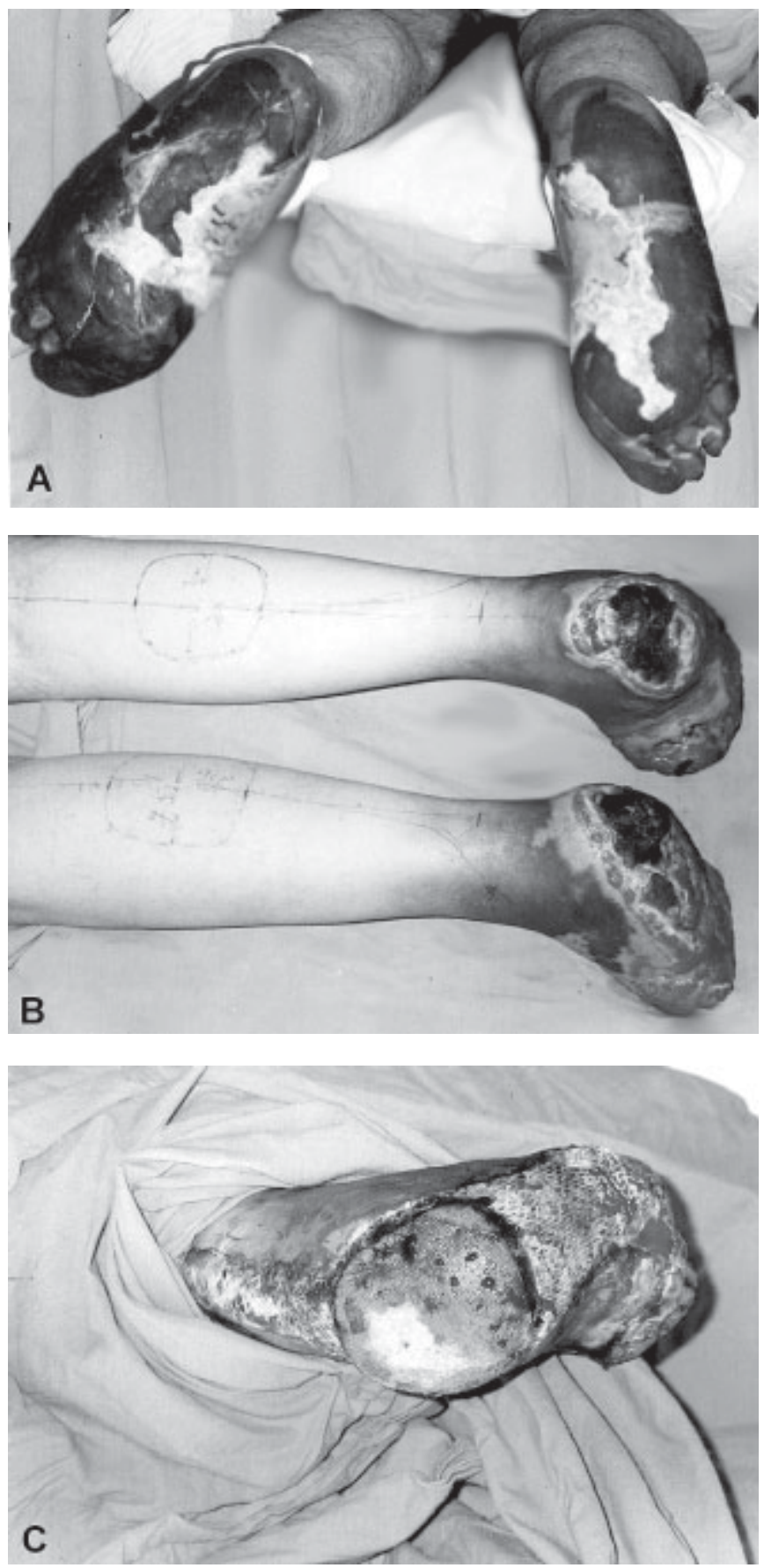

Fig. 1. A. patient with frostbite of both feet. B. Two sural flaps were applied. C. Complete flap loss of sural flap of left food was observed. Result 4 day p.o.

Patient No. 2 Male, aged 47, admitted to hospital one week after thermal hot surface contact burn of the left heel and foot. Local infection was present. After drainage of the wound, treatment with antibiotics and debridement, the heel defect was covered with sural flap, with skin island size $6 \times 7 \mathrm{~cm}$. The donor site and the foot defect were skin grafted. The flap survived completely. The rest of the wound was covered with free skin graft (fig. 2)
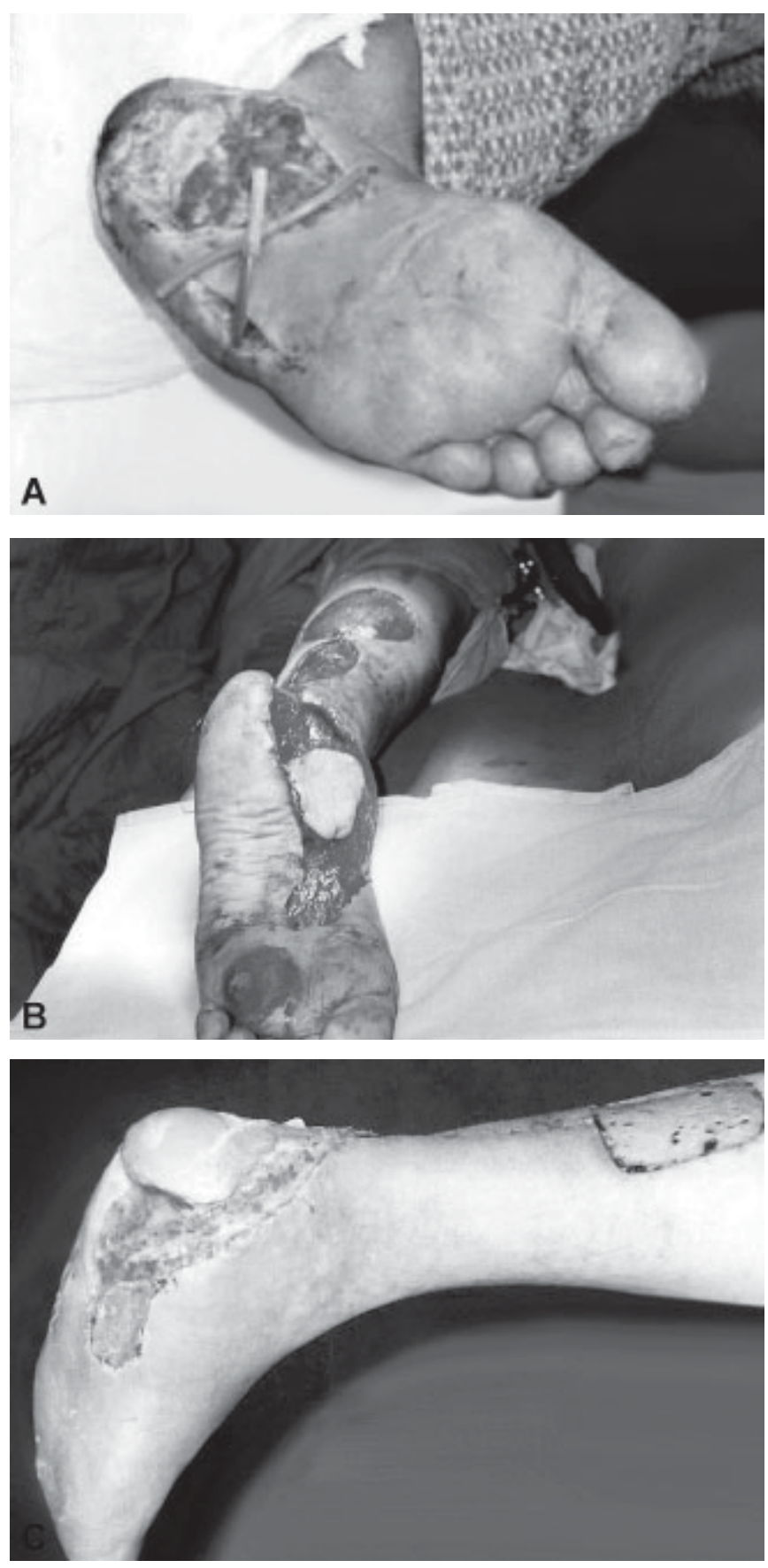

Fig. 2. A. Patient with infected deep burn of the left heel, foot with drainage. B. Distal sural flap was elevated. C. Result 14 days p.o.

Patient No. 3 Female, aged 77, with III degree flame burn of the right thigh, knee joint and lower leg. During necrectomy destroyed periost and partial necrosis of the patella were observed. After debridement medial gastrocnemius flap was applied. Thigh and lower leg wounds were covered with skin graft. The flap survived completely. Partial lesion of the free skin graft was observed. 

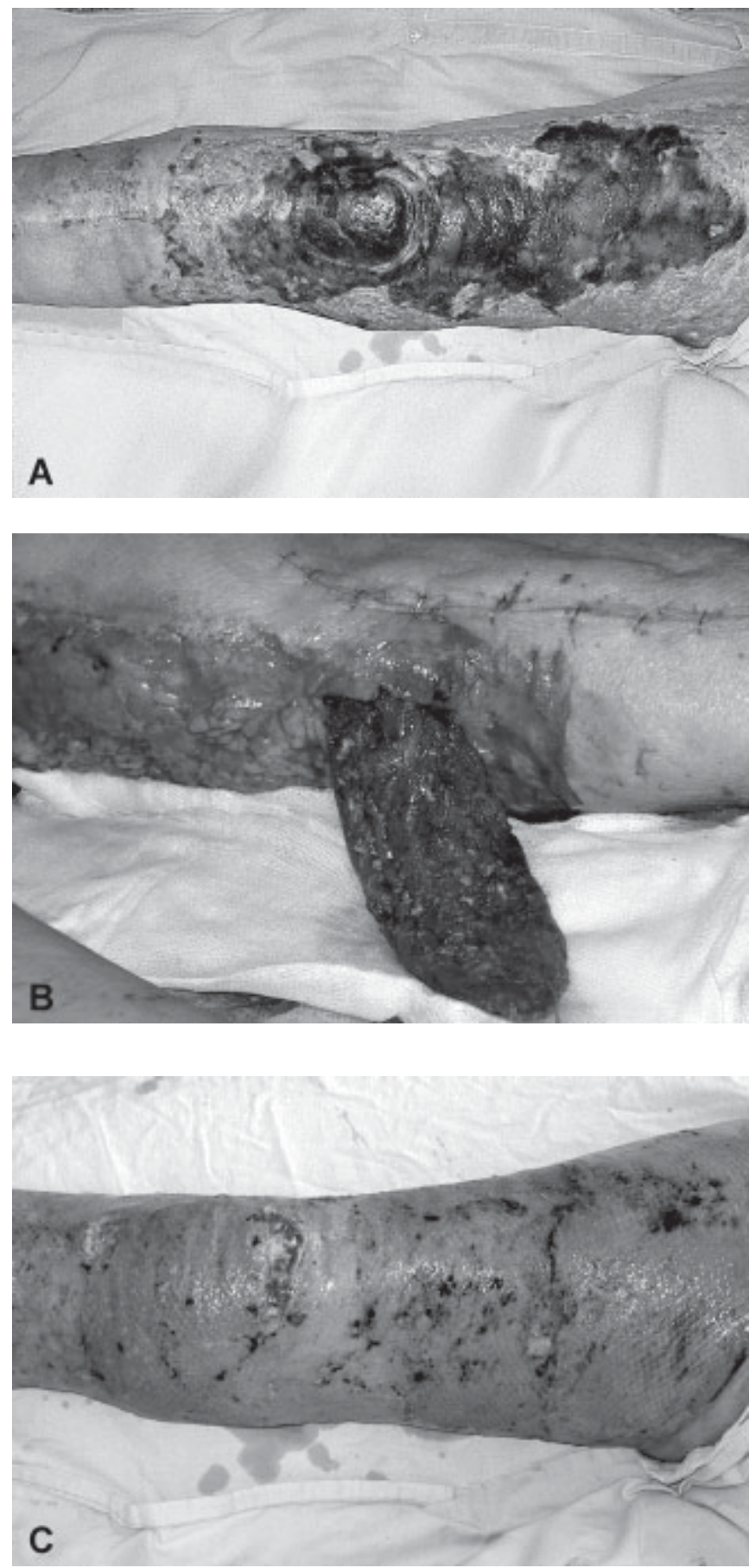

Fig. 3. A. Flame burn III degree of the knee . B. The knee wound was covered with medial gastrocnemius flap. C. 20 days post operation.

Patient No. 7 Male, 42 year old, with traumatic defect of the left foot, observed osteomyelite of calcaneus bone. After debridement the defect of the heel was covered with distally based sural flap $7 / 6 \mathrm{~cm}$ (fig. 4). The donor site and wound of the foot were covered with skin graft. Necrosis of the distal edge of the flap appeared. The residual defect was skin grafted.

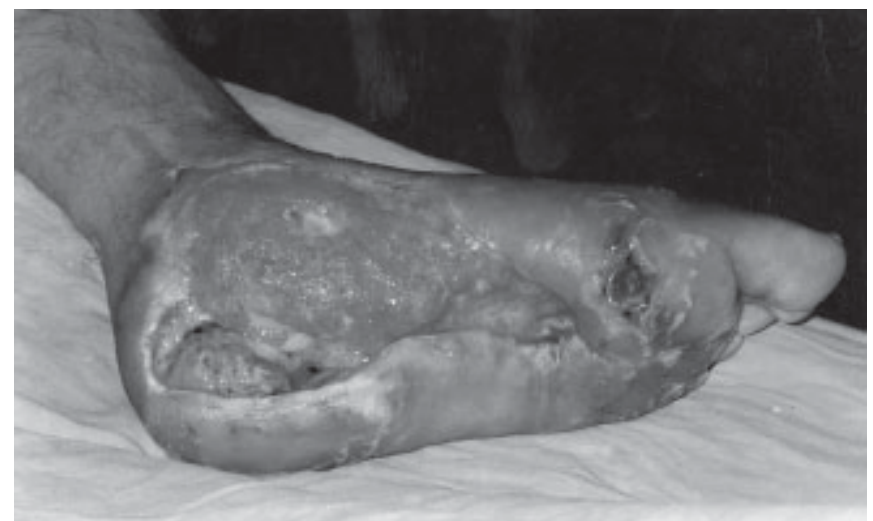

A

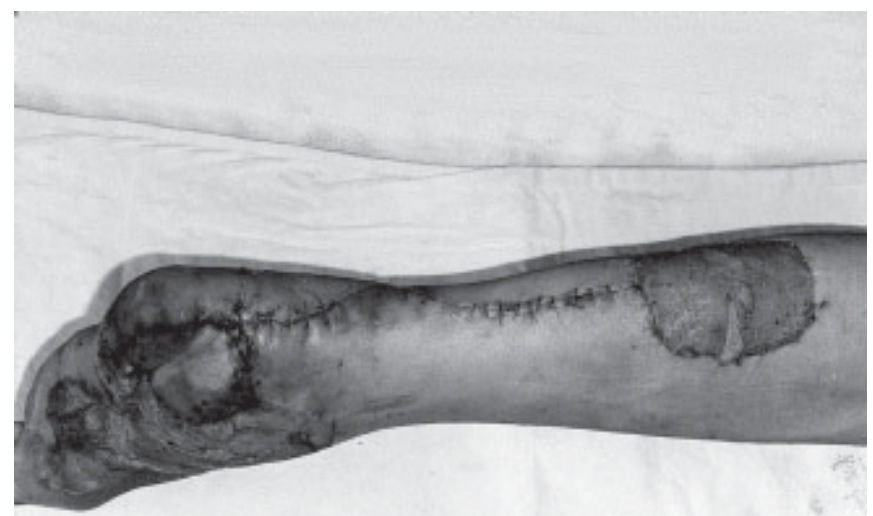

B

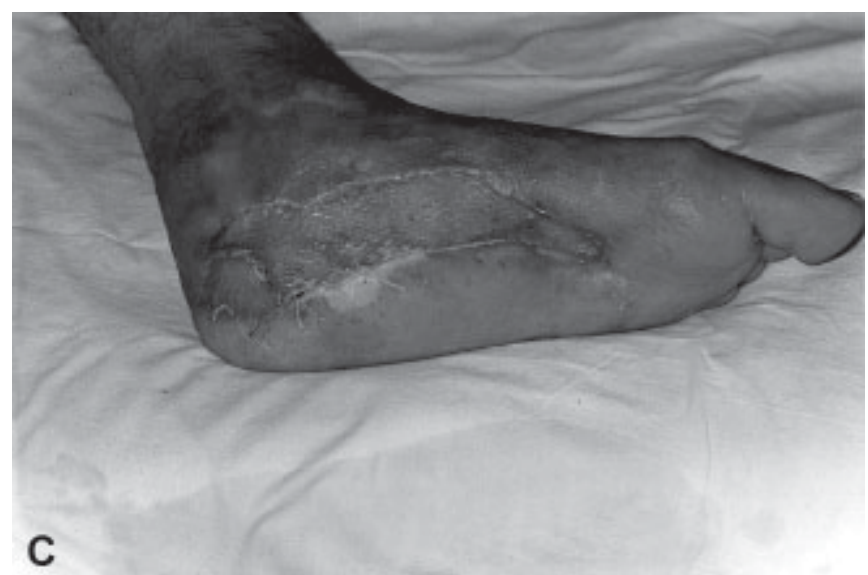

Fig. 4. A. Post traumatic defect of the foot. B. The defect was treated with distally based sural flap and the foot wound was covered with skin graft. C.30 days after operation 


\section{DISCUSSION}

The aim of the reconstructive work of the lower leg is to obtain adequate functional and aesthetic results with minimal donor site morbidity. In cases of full destruction of the skin alone, debridement followed by skin grafting is the most common method of treatment. When trauma extends deeper and results in either bone devoid of periosteum, exposure of tendons, open joint or observed infection, traditional skin grafting is not suitable. Random flaps consisting of skin and subcutaneous tissue that survive based on its own blood supply can be applied in small size wounds (3).Unlike random flaps, pedicled and free flaps have much wider application in the treatment of deep wounds because of their flexibility in size, high survival rate, and stable soft tissue coverage (4).Free flap transfers can provide good coverage in one stage (5). However, the disadvantages associated with the application of free flaps are donor-site morbidity, long operating hours, besides they require a practiced surgical team. Free flaps are suitable in cases when the availability of local flaps is limited in patients who have suffered from deep burn or other trauma with surrounding tissue necrosis $(6,7)$.

The gastrocnemius muscle flap, described by Ger R. (in 1971) as a muscle flap (8), is used in cases of exposed bones, tendons, damaged patella tendon, or open knee joint. The flap is widely applied to cover defects of the knee, the proximal tibia and femur (9). The lateral head of the muscle, compared to the medial, is used more rarely in reconstructive surgery(10). The reasons for its restricted use are the size and the limited arc of rotation as well as the potential risk of peroneal nerve palsy of the muscle that might be caused by the surgical procedure itself (11) The medial head of the gastrocnemius muscle, which is the part mostly used, meets all requirements needed for a successful wound coverage (13). Certainly there are cases when the application of the lateral head is preferred and that happens in cases of wounds in the proximal part of the tibia and the lateral surface of the knee. There are disadvantages associated with the application of the gastronemius flap such as deformation of the donor area (14). Additional damage to the donor site is caused by the application of the myocutaneous gastrocnemius flap, proposed by $\mathrm{Mc}$ Craw (in 1976), and it requires subsequent coverage of the donor site with free skin graft (20). For that reason we prefer the application of the muscle flap alone which is subsequently covered with free skin graft. In our experience the advantages of the gastrocnemius flap prevail over its disadvantages. The surgical technique is relatively easy to perform and it requires less time than free tissue transfers. Furthermore, the gastrocnemius flap provides better tissue coverage, greater stability to the knee joint.

The distally based sural flap, reported by Masquelet et al. (1992), is a very popular method to cover defects of heel and foot (15). The vessel pedicle consists of sural nerve, superficial sural artery and a vein. The sural flap could be applied in defects with different etiology such as burns, frostbites, mechanical traumas, difficult healing wounds(16). The main problem observed in this kind of flap is venous congestion which is a serious condition that requires prompt treatment (17). In order to avoid it, Yilmaz et al. leave a distally extended skin island (18). Thus, the pressure on the flap vessel is decreased. Other authors have proposed delayed sural flap to diminish the level of flap necrosis (19).

The sural flap has a number of advantages for the coverage of large and deep defects of the foot: good blood supply; small deformation of the donor site; easy dissection; no damage to big vessels. It has large arc of rotation and does not require sacrifice of any major artery, and, as a result, moderate-to-large-sized defects can be covered adequately. The dissection technique is simple, and donor site morbidity is minimal.

\section{CONCLUSION}

The pedicle fasciocutaneous and muscle flaps are used in reconstructive surgery to treat large and deep defects of the lower leg. Full tissue coverage, functional recovery and good aesthetic results are achieved with minimum damage to the donor site. In addition, the surgical procedure is relatively short and easy to perform, and it doesn't require microsurgical skills and instruments.

\section{REFERENCES:}

1. Pu LL, Thomson JG. Salvage of the exposed irradiated knee joint with free tissue transfer. Ann Plast Surg. 2000 Mar;44(3):334-9. [PubMed]

2. Pers M, Medgyes S. Pedicle muscle Flaps and their application in the surgery of repair. Brit J Plast Surg. 1973 Oct;26(4):313-21. [PubMed]

3. Daigeler A, Drucke D, Tatar K. Homann HH, Goertz O, Tilkorn D, et al.
The Pedicled Gastrocnemius Muscle Flap: A Review of 218 Cases. Plast Reconstr Surg. 2009 Jan;123(1):250-257. [PubMed] [CrossRef]

4. Uygur F, Duman H, Ulkur E, Celikoz B. Are Reverse Flow Fasciocutaneous Flaps an Appropriate Option for the Reconstruction of Severe Postburn Lower Extremity Contractures? Ann Plast Surg. 2008
Sep;61(3):319-324. [PubMed] [CrossRef]

5. Ulusal AE, Ulusal BG, Lin YT, Lin $\mathrm{CH}$. The advantages of free tissue transfer in the treatment of posttraumatic stiff knee. Plast Reconstr Surg. 2007 Jan;119(1):203-210. [PubMed] [CrossRef]

6. Balakrishnan C, Flanagan T, Klein J, Erella VS, Saini MS. Soft tissue 
coverage of the knee joint following burns, Can J Plast Surg. 2006; 14(3):163-166. [PubMed]

7. Mozafari N, Moosavizadeh SM, Rasti M. The distally based neurocutaneous sural flap: A good choice for reconstruction of soft tissue defects of lower leg, foot and ankle due to fourth degree burn injury. Burns. 2008, May;34(3):406-411. [PubMed] [CrossRef]

8. Ger R. The technique of muscle transposition in the operative treatment of traumatic and ulcerative lesions of the leg. J Trauma. 1971 Jun;11(6):50210. [PubMed]

9. Boopalan PR, Nithyananth M, Jepegnanam TS. Lateral Gastrocnemius Flap Cover for Distal Thigh Soft Tissue Loss. J Trauma-Injury Infection \& Critical Care. 2010, Nov;69(5):E38-E41. [CrossRef]

10. Daigeler A, Drucke D, Tatar K, Homann HH, Goertz O, Tilkorn D, et al. The pedicled gastrocnemius muscle flap: a review of 218 cases. Plast Reconstr Surg. 2009 Jan;123(1):250-257.
[PubMed] [CrossRef]

11. Sanger JR, Kao DS, Hackbarth DA. Peroneal nerve compression by lateral gastrocnemius flap. J Plast Reconstr Aesthet Surg. 2009 Aug; 62(8): e280-282. [PubMed] [CrossRef]

12. Veber M, Vaz G, Braye F, Carret JP, Saint-Cyr M, Rohrich RJ, et al. Anatomical Study of the Medial Gastrocnemius Muscle Flap: A Quantitative Assessment of the Arc of Rotation. Plast Reconstr Surg. 2011 Jul;128(1):181-187. [PubMed] [CrossRef]

13. Jepegnanam TS, Boopalan PR, Nithyananth M, Titus VT. Reconstruction of complete knee extensor mechanism loss with gastrocnemius flaps. Clin Orthop Relat Res. 2009 Oct;467(10): 2662-7. [PubMed] [CrossRef]

14. McCraw JB, Fishman JH, Sharzer LA. The versatile gastrocnemius myocutaneous flap. Plast Reconstr Surg. 1978 Jul;62(1):15-23. [PubMed]

15. Masquelet AC, Romana MC, Wolf G. Skin island flaps supplied by the vascular axis of the sensitive superficial nerves: Anatomic study and clinical experience. Plast Reconstr Surg, 1992 Jun;89(6):1115-21. [PubMed]

16. Afifi AM, Mahboub TA, Losee JE, Smith DM, Khalil HH. The Reverse Sural Flap: Modifications to Improve Efficacy in Foot and Ankle Reconstruction. Ann Plast Surg. 2008, Oct; 61(4):430-436. [PubMed]

17. Romansky R, Dimov V, Milev S, Minkov G, Arguirova M, Laftsis A. Application of distally based sural flap for defect coverage of the lower leg and foot. Bul J Ortop Trauma. 2011, 48(1):30-38.

18. Yilmaz M, Karatas O, Barutcu A. The distally based superficial sural artery island flap: Clinical experiences and modifications. Plast Reconstr Surg. 1998 Dec;102(7):2358-67. [PubMed]

19. Erdmann D, Gottlieb N, Humphrey JS, Le TC, Bruno W, Levin LS. Sural flap delay procedure: A preliminary report. Ann Plast Surg. 2005 May;54(5):562. [PubMed]

Address for correspondence:

Dr.Yolanda Zayakova

Department of Burns, Plastic and Aesthetic Surgery, Multi-profile Hospital for Active Treatment - Varna, e-mail: zayakova@yahoo.com; 